Başvuru : : 13.07.2018

Kabul : :04.04.2019

\title{
Veri Zarflama Analizi ile Ortadoğu ve Kuzey Afrika (MENA) Ülkelerinin Etkinliklerinin Karşılaştırılması ${ }^{1}$
}

\author{
Şeyda Nur Alaş² \\ Emre İpekçi Çetin ${ }^{3}$
}

Veri Zarflama Analizi ile Ortadoğu ve Kuzey Afrika (MENA) Ülkelerinin Etkinliklerinin Karşılaştırılması

Öz

Ortadoğu ve Kuzey Afrika ülkelerindeki ekonomik ve politik gelişmelerle birlikte bu ülkelerde ki girişimler ve ekonomik faaliyetler artmaktadır. Bu çalışmada veri zarflama analizi kullanılarak MENA ülkelerinin ekonomik etkinliklerinin elde edilmesi amaçlanmaktadır. Çalışmaya verilerine eksiksiz olarak ulaşılabilen 20 ülke dahil edilmiştir. Girdi değişkenleri olarak bağımlı nüfus oranı, enflasyon oranı, işsizlik oranı ve mal ithalatı, çıktı değişkenleri olarak kişi başı GSYiH, mal ihracatı ve istihdam oranı alınmıştır. Çıktı yönlü CCR ve çıktı yönlü BCC modelleri kullanılarak etkin olan ve olmayan ülkeler ile referans alınan ülkeler belirlenmiştir. BAE, Bahreyn, İsrail, Katar, Malta, Suudi Arabistan ve Umman ülkelerinin her iki modele göre de teknik etkin olduğu ortaya çıkmıştır.

\begin{abstract}
Comparison of the Efficiencies of the Countries of the Middle East and North Africa (MENA) Using Data Envelopment Analysis

\section{Abstract}

With the economic and political developments in the Middle East and North African countries, the initiatives and economic activities in these countries are being enhanced. In this study, it is aimed to obtain economic efficiency of MENA countries using data envelopment analysis. 20 countries with complete access to data have been included in the study. Dependent population ratio, inflation rate, unemployment rate and imports of goods were taken as input variables while percentage of per capita GDP, exports and employment were taken as output variables. Output-oriented $\mathrm{CCR}$ and outputoriented BCC models were used to determine the efficient and non-efficient countries and reference countries. BAE, Bahrain, Israel, Qatar, Malta, Saudi Arabia and Oman countries have occurred to be technically efficient in both models.
\end{abstract}

Anahtar Kelimeler: Veri Zarflama Analizi, MENA, Keywords: Data Envelopment Analysis, MENA, Economic Ekonomik Etkinlik

Efficiency.

\section{Giriş}

Ortadoğu ve Kuzey Afrika Bölgesinde bulunan ülkeler günden güne başta enerji kaynakları olmak üzere önemli maden rezervleri ile ülkemizin ve dünyanın gündemine girmektedir. Bu ülkelerde bulunan girişimlerin ve ekonomik faaliyetlerin arttığı görülmektedir. Bölgede bulunan ülkelerin yaşadığı gelişmeler hem ekonomistler için hem de bu bölgede yatırım düşüncesine sahip olan girişimcilerimiz için büyük öneme sahiptir. Dünya Bankası'nın bilgilerine göre İsrail ve Filistin (Batı Şeria ve Gazze) dâhil 22 ülkeden oluşan bu bölge;

\footnotetext{
${ }^{1}$ Bu çalışma, Antalya Akdeniz Üniversitesi, Sosyal Bilimler Enstitüsü, Ekonometri Anabilim Dalı́nda, Doç. Dr. Emre İpekçi Çetin danışmanlığında, Şeyda Nur Alaş tarafından "Veri Zarflama Analizi ile Ortadoğu ve Kuzey Afrika (MENA) Bölgesi'ndeki Ülkelerin Etkinliklerinin Karşılaştırılması” ismiyle tamamlanarak 12.07.2016 tarihinde savunulan yüksek lisans tezinden türetilmiştir.

2 Yüksek Lisans Öğrencisi, Akdeniz Üniversitesi, Sosyal Bilimler Enstitüsü, alas.seyda@gmail.com, Yazar ORCID bilgisi: https://orcid.org/0000-0003-3565-7291.

3 Doç. Dr., Akdeniz Üniversitesi, iïBF, Ekonometri Bölümü, ecetin@akdeniz.edu.tr, Yazar ORCID bilgisi: https://orcid.org/0000-0002-8108-1919.
} 
akademik, askeri ve ticari olarak MENA (Middle East and North Africa - Ortadoğu ve Kuzey Afrika) bölgesi olarak adlandırılmaktadır. Atlas Okyanusu'ndan Umman Denizi'ne kadar olan bölgede Kuzey Afrika ülkeleri, Arap Yarımadası'ndaki ülkeler ve İran'ın bulunduğu alandaki ülkeleri yer almaktadır (HSCB Bank, 2011: 1; Sözen, 2011: 120). MENA bölgesi İsrail hariç büyük çoğunluğu Arap veya İslam vasıfları ile ön plana çıkan ülkelerden oluşmaktadır. MENA bölgesinde yer alan ülkeler; Birleşik Arap Emirlikleri (BAE), Bahreyn, Cezayir, Cibuti, Fas, Filistin (Batı Şeria ve Gazze), Irak, İran, İsrail, Katar, Kuveyt, Libya, Lübnan, Malta, Mısır, Suriye, Suudi Arabistan, Tunus, Umman, Ürdün ve Yemen'dir. MENA bölgesi için bazen daha geniş tanımlamalar da kullanılmaktadır. Bu tanımlamalarda bölgenin bir parçası olarak Türkiye, Somali ve Sudan da bu coğrafyaya ikinci dereceden dâhil edilmektedir. Somali ve Sudan Birleşmiş Milletler Kalkınma Programı'nın (UNDP- United Nations Development Programme) yaptığı sınıflandırmada bu ülkelere ek olarak dâhil edilmektedir (Genç ve Sayım, 2011: 15).

MENA bölgesinin, hem doğal hem de jeopolitik açıdan dünyada önemli bir konumu vardır. MENA, daraltılmış sınırlarına göre, 540 milyona yakın insanıyla dünya nüfusunun $\% 6$ 'sını temsil etmektedir. Bu bölgede en az nüfuslu ülke 1,3 milyon kişiyle Bahreyn, en kalabalık nüfuslu ülke yaklaşık 80 milyon ile Mısır'dır (Kalaycı, 2011: 178). Bölge dünya petrol rezervlerinin \%60'dan fazlasına, doğal gaz rezervlerinin ise \%45'ine sahiptir. Petrol ihraç Eden Ülkeler Örgütü (OPEC) üyesi olan 12 ülkenin 8 tanesi (BAE, Cezayir, Irak, İran, Katar, Kuveyt, Libya ve Suudi Arabistan) MENA bölgesinde yer almaktadır. MENA bölgesi büyümeyi sağlamak için artan bir şekilde kendi finansal kaynaklarına ihtiyaç duymaktadır. Bu noktada, bölge insanının emek faktörünün yanında sermaye yönünün de olması bölgenin ekonomik yapısının öne çıkan özelliklerinden biridir (Devlin, 2010: 2; Genç ve Sayım, 2011: 16).

Günümüzde ihtiyaçlar hızla artarken kaynaklar ise günden güne azalmaktadır. Kaynakların gelecek nesillere aktarılabilmesi ancak etkin ve verimli bir kullanımla mümkündür. Etkinlik, belirli bir miktardaki çıktıyı üretmek üzere en az girdiyi kullanmak veya elimizde bulunan kaynakları kullanarak en fazla çıktıyı üretmektir. Verimlilik ise çıktı ile bu çıktıyı üretmek üzere kullanılan girdi arasındaki oranı ifade eder. Drucker'a göre (1994); verimlilik işlerin doğru yapılmasıyla ilgili bir kavram, etkinlik ise doğru işlerin yapılmasıyla ilgili bir kavramdır.

Rekabet koşullarında bir yandan ülkeler üretimlerinde artışa gitmeye zorlanırken diğer yandan kaynakların verimli ve etkin kullanılması gerekliliği ortaya çıkmaktadır. Ülkelerin etkinliklerinin incelenmesinde bir takım sayısal yöntemlerin kullanıldığı görülmektedir. Etkinlik ölçüm yöntemleri oran analizi, parametrik yöntemler ve parametrik olmayan yöntemlerdir. Bu yöntemlerin en basiti olan oran analizi, tek girdinin tek çıktıya oranıdır (Kavuncubaşı ve Ersoy, 1995: 78). Parametrik yöntemlerden en fazla kullanılan etkinlik ölçüm yöntemi regresyon analizidir. Regresyon analizi ile çoklu girdi ve tek bir çıktı arasındaki ilişki incelenir. Parametrik olmayan yöntemler arasında en sık kullanılan yöntem ise Veri Zarflama Analizi (VZA)'dir. VZA, kâr amacı gütsün veya gütmesin, çoklu girdilerin çoklu çıktılara dönüştürüldüğü süreçte her bir girdi ve çıktıyı ayrı ayrı ağırlıklandırmak suretiyle performans değerlendirmesine olanak sağlayan bir yöntemdir.

$\mathrm{Bu}$ çalışmanın amacı MENA ülkeleri düzeyinde bazı ekonomik göstergeleri kullanarak etkinlik analizi yapmaktır. MENA bölgesinde yer alan ülkeler yıllar içinde çeşitli ekonomik gelişmelere ulaşmışlardır. Literatürde bu bölgedeki ülkelerin verimliliklerinin ölçümü ile ilgili çeşitli karşılaştırmalı ve ekonometrik analizler mevcuttur. Bu çalışmada MENA ülkelerinin ekonomik verimliliklerinin analizinde VZA kullanılmasıyla ülkelerin karşılaştırmalı etkinliklerinin elde edilmesi amaçlanmaktadır. 


\section{Literatür Taraması}

Uygulama bölümüne geçmeden önce ülkelerin ekonomik, sosyoekonomik ve makro ekonomik performanslarının incelendiği çalışmalardan derlenerek hazırlanan literatür taraması özetlenmiştir. Konuyla ilgili olarak yapılmış olan çalışmalardan örnekler aşağıdaki kısımda anlatılmaktadır.

Martić ve Savić (2001), Sırbistan bölgelerinin sosyoekonomik gelişmişlik düzeylerine göre değerlendirmesini ve sıralamasını yapmışlardır. VZA'nın çıktı yönlü CCR modelinin kullanıldığı bu çalışmada girdi olarak tarıma elverişli alan, sabit sermaye oluşumu, elektrik tüketimi ve nüfus, çıktı olarak ise gayri safi yurt içi hasıla, toplam hekim sayısı, toplam ilköğretim öğrenci sayısı ve sosyal sektördeki toplam istihdam sayısı kullanmışlardır. Sonuç olarak ise incelenen 30 bölgeden 17 sinin etkin çıktığı ve etkin bölgeler arasında 1. sırada Belgrad şehrinin son sırada ise Rasina bölgesinin yer aldığı görülmüştür.

Güran ve Cingi (2002), 55 ülkedeki devletin ekonomik müdahalelerinin ekonomik çıktıları üzerindeki etkisini VZA kullanarak ölçmüşlerdir. Çalışmada merkezi hükümet harcamalarının GSYiH'ya oranı ve ekonomik düzenleme derecesi girdi olarak kullanılmıştır. Çıktı olarak ise tahsis işlevinin başarı düzeyini temsil eden göstergeler olarak sağlık, eğitim ve altyapı hizmetleri, istikrar işlevinin başarı düzeyi olarak enflasyon ve işsizlik endeksi, büyüme işlevi başarı düzeyi olarak kişi başına gelir ve gelir dağılımı işlevinin başarı düzeyi olarak ise gini katsayısı kullanılmıştır. Yapılan çalışma sonucunda genel olarak ülkelerin ekonomik çıktıları üzerinde düzenleme aracının harcama aracına göre daha belirleyici olduğu ve devlet müdahalesindeki başarı düzeyinin gelişmişlik düzeyi ile ilişkili olduğu bulunmuştur.

Ramanathan (2006), Orta Doğu ve Kuzey Afrika (MENA) Bölgesinde yer alan 18 ülkenin ekonomik ve sosyal performansları VZA ile karşılaştırmıştır. Çalışmada 1997, 1998 ve 1999 yıllarına ait sosyo-ekonomik verileri temsil eden toplam işgücünün nüfusa oranı, doğuşta beklenen yaşam süresi, ilköğretimdeki öğretmenlerin sayısı ve kişi başı GSYiH değişkenleri girdi olarak, yaş bağımlılık oranı, okuma yazma bilmeyenlerin oranı ve bebek ölüm oranı değişkenleri ise çıktı olarak kullanılmıştır. 1999 yılına ait veriler ile yapılan analiz sonucunda Bahreyn, Ürdün, Kuveyt ve BAE en verimli, Yemen ise en verimsiz ülke olmuştur. Etkinlik skorları ve değişkenler kullanılarak yapılan regresyon analizi sonucunda etkinlik skorları ile ülkelerin zenginliği (kişi başı düşen GSMH açısından) arasında anlamlı fakat ülkelerin büyüklüğü (nüfus açısından) ile anlamsız bir ilişki olduğu görülmüştür. Bir başka adımda ise ülkelerin performansları zaman serisi analizi olan Malmquist Verimlilik Endeksi (MPI) kullanılarak incelenmiştir. Bu analiz sonucunda ise 1999 yılının 1998 yılına göre çıktıların yüksek değerlerde olduğuna, girdilerin ise düşük değerlerde olduğu görülmüştür. 1998-1999 yılları süresince teknolojideki değişim MPI iyileştirmesinde teknik etkinlikteki değişimden daha fazla katkıda bulunmuştur.

Aslankaraoğlu (2006), çalışmasında AB üyesi 25 ülke ve 3 aday ülkenin 1998-2003 yılları sosyoekonomik verileri kullanılarak Malmquist Verimlilik Endeksi ile yıllar arasındaki toplam faktör verimlilikleri incelemiştir. Daha sonra VZA modelleri ile 2003 yılı için göreli etkinlikleri hesaplamıştır ve temel bileşenler analizi ile ülkeler sıralanarak aralarındaki ilişki spearman korelasyon testi ile belirlenmiştir. Çalışmada kullanılan değişkenlerden eğitim harcamaları, istihdam oranı ve gayri safi sabit sermaye girdi, GSYiH, ihracatın ithalata oranı ve öğrenci sayısının nüfus içindeki payı ise çıktı olarak kullanılmıştır. Malmquist Verimlilik Endeksi ile incelenen faktör verimliliği sonucunda en yüksek toplam faktör verimliliğine sahip ülkenin Lüksemburg, en yüksek düşüşe sahip olan ülkenin ise Bulgaristan olduğu görülmüştür. VZA 
etkinlik skorlarına göre birinci sırada yer alan Lüksemburg temel bileşenler analizinde 12 . sırada ve VZA'da son sırada yer alan Portekiz ise temel bileşenler analizinde 24. sırada yer aldığı görülmüştür. İki analiz arasındaki korelasyon katsayısının ise 0,875 olduğu görülmüştür.

Mohamad (2007), Asya Pasifik ülkelerinin 1996, 2000 ve 2003 yıllarına ait makroekonomik performanslarını VZA kullanarak incelemiştir. Yaptığı çalışmada VZA modellerinden çıktı yönlü CCR modelini kullanan Mohamad, ülkeler için sıralamayı Andersen Petersen süper etkinlik yöntemini kullanarak yapmıştır. Makroekonomik veriler içerisinden devlet harcamalarının GSYiH yüzdesini girdi, GSYIH'nin yıllık büyüme oranı, istihdam oranı, ticaret oranı ve enflasyon oranını ise çıktı olarak kullanmıştır. 1996 ve 2000 yıllarında on ülke, 2003 yılında ise 8 ülke etkin çıkmıştır. 1996 ve 2000 yıllarında etkin olan Endonezya, Japonya ve Singapur 2003 yılında etkin değildir. Azerbaycan, Bangladeş ve Kamboçya ise her üç yıl içinde etkinliğini korumuştur. Andersen Petersen süper etkinlik sıralamasında ise 1996 yılında Endonezya, 2000 yılında Bangladeş ve 2003 yılında Macao birinci sırada yer almıştır.

Deliktaş (2008), Sovyet Sosyalist Cumhuriyetler Birliği ülkelerinin zaman periyotlarına göre teknik etkinlik ve toplam faktör verimliliği artışını incelemiştir. Geçiş dönemi öncesi olan 19701989 yılları ve geçiş dönemi olan 1991-2003 yıllarının ekonomik performansları VZA kullanılarak karşılaştırılmıştır. Ayrıca geçiş dönemi ekonomileri için Malmquist Toplam Faktör Verimliliği hesaplanmıştır. Girdi olarak geçiş öncesi dönem için istihdam sayısı ve öz sermaye, geçiş dönemi için ise toplam işgücü ve öz sermaye kullanılmıştır. Çıktı olarak ise geçiş öncesi dönem için net ürün temini, geçiş dönemi için ise GSYiH kullanılmıştır. VZA sonuçlarına göre geçiş öncesi dönem için en verimli ülke Belarus ve Letonya, en verimsiz ülke Türkmenistan olarak, geçiş döneminde ise en verimli ülke olarak Litvanya, en verimsiz ülke olarak Tacikistan bulunmuştur. Geçiş dönemi ile ekonomi düzeylerinde artış olduğu görülmüştür.

Karabulut vd. (2008), Türkiye ve Avrupa Birliğine üye ülkelerin 2001-2005 yılları için makroekonomik performans düzeylerini VZA ve Malmquist Toplam Faktör Verimliliği yöntemlerini kullanarak ölçmüşlerdir. Çalışmalarında makroekonomik girdi olarak istihdam ve gayri safi sermaye oluşum değerlerini, çıktı olarak ise cari fiyatlarla gayri safi yurt içi hasıla değişkenlerini kullanmışlardır. Türkiye'nin teknik etkinlik endeksinin birçok $A B$ ülkesini geride bırakarak 5. sırada yer aldığı fakat toplam faktör verimlilik endeksine bakıldığında ise Türkiye'nin 21. sırada yer aldığı görülmüştür.

Mohamad ve Said (2011), İslam İşbirliği Teşkilatına üye 54 ülkenin makroekonomik performanslarını karşılaştırmışlardır. 2003-2007 yılları için yapılan bu karşılaştırmada VZA'nın çıktı yönlü CCR modelini kullanmışlardır. Çalışmada GSYiH'nin bir yüzdesi olarak toplam devlet harcamalarını girdi olarak, ihraç edilen malların ithal edilen mallara oranı, istihdam oranı, GSYiH büyüme oranı ve enflasyon oranı ise çıktı olarak kullanılmıştır. Yapılan analizde teknik etkinlik sonuçlarına bakıldığında Burkina Faso, Azerbaycan, Çad, Libya, Guyana, Katar ve Uganda'nın etkin ülkeler, Mısır, Türkiye, Yemen ve İran'ın ise en düşük etkinliğe sahip ülkeler olduğu görülmüştür.

Koçak ve Çilingirtürk (2011), çalışmasında AB üyesi 27 ülke ve aday 3 ülkenin 2002-2006 yıllarına ait iktisadi değişkenlerin göreli etkinliklerinin VZA ile incelemiştir. Analiz için iktisadi değişkenleri temsil edecek 4 girdi ve 11 çıktı kullanılmıştır. Almanya, Makedonya, Avusturya, Çek Cumhuriyeti, Hollanda, İsveç, Lüksemburg, Polonya ve Slovakya 2006 yılına kadar geçen süreçte etkinlik sıralamalarını artırdığı görülmüştür. 
Demirci (2012), İktisadi İşbirliği ve Kalkınma Teşkilatı (OECD) ülkelerinin ekonomik ve sosyal etkinliklerini VZA kullanarak belirlemiştir. Bu çalışmada ekonomik değişkenlerden işsizlik oranı, yıllık ortalama çalışma süresi, doğrudan yabancı yatırımlar, gıda üretim indeksi, toplam ithalat ve vergi geliri girdi olarak, kişi başı gayri safi milli hasıla, satın alma gücü paritesi, kıyaslamalı fiyat indeksi, gelir indeksi, toplam ihracat ve kişi başı $\mathrm{CO}_{2}$ emisyonu ise çıktı olarak kullanılmıştır. Sosyal değişkenlerden ise $1 \mathrm{~km}^{2}$ başına düşen nüfus, hizmet çalışanlarının toplam çalışanlara oranı, toplam enerji üretimi ve toplam sağlık harcamaları girdi olarak, toplam enerji tüketimi, toplam mobil telefon abone sayısı, sağlık indeksi ve ortalama yaşam süresi de çıktı olarak kullanılmıştır. 2006-2010 yılları için yapılan analizlerde sonuçlar ekonomik ve sosyal olarak ayrı ayrı değerlendirilmiş ve daha sonra karşılaştırılmıştır. Sonuç olarak ülkelerin ekonomik etkinlikleri ile sosyal etkinlikleri arasında ilişkisi olmadığı görülmüştür. Ekonomik etkinlik sonuçlarına göre tüm yıllar için Almanya, Amerika, Avusturalya, Danimarka, Estonya, Hollanda, İrlanda, İsviçre, İzlanda, Japonya, Kore, Lüksemburg, Meksika, Norveç, Slovenya ve Şili'nin etkin ülkeler olduğu bulunmuştur.

Öner (2013), Türkiye'deki illerin ekonomik performanslarını VZA ve temel bileşenler analizi yöntemleri ile değerlendirmiştir. illerin ekonomik performanslarını belirleyecek olan nüfus ve yatırım teşvikleri girdi değişkenleri olarak, ihracatın ithalata oranı, sanayi sicil kayıtlarına göre istihdam oranı ve kişi başına düşen katma değer ise çıktı değişkenleri olarak kullanılmıştır. Çalışmada kullanılan VZA'nın çıktı yönlü BCC modeli sonucunda Antalya, Bolu, Edirne, Gümüşhane, İstanbul dâhil 23 il etkin durumdadır. Temel bileşenler analizi ile bulunan etkinlik skorlarına bakıldığında ise birinci sırada Tekirdağ, son sırada ise Şanlıurfa yer almıştır.

Demireli ve Yüksek Özdemir (2013), 13 Avrupa ülkesinin 2005-2011 yıllarına ait verilerini kullanarak makroekonomik performanslarını incelemişlerdir. Girdi değişkenleri; GSYiH'nin yüzdesi olarak toplam devlet harcamaları ve çıktı değişkenleri ise GSYiH, 15-64 yaş istihdam oranı ve ihracatın ithalata oranıdır. Ülkelerin etkinliklerini VZA'nın CCR modeli ve stokastik VZA'nın şans kısıtlı VZA modelleri ile hesaplamış ve sonuçları karşılaştırmışlardır. İki model içinde hesaplanan etkinlik sonuçlarının benzer olduğu görmüşlerdir. İki model sonucunda da yılların tümünde etkin çıkan iki ülke Almanya ve Norveç'tir. Ayrıca sonuçlar yıllar itibarıyla incelendiğinde ise iki modelde de 2008 yılındaki düşüşün ardından 2009 yılında artış olurken 2010 yılından sonra tekrar düşüş olduğu gözlemlenmiştir.

Demir ve Bakırcı (2014), çalışmalarında 34 OECD ülkesinin 2006-2010 yılları için ekonomik etkinliklerini VZA ile incelemişlerdir. İşsizlik oranı, yıllık ortalama çalışma süresi, doğrudan yabancı yatırımlar, gıda üretim indeksi, toplam ithalat ve vergi geliri girdi değişkenleri, kişi başı gayri safi milli hasıla, satın alma gücü paritesi, kıyaslamalı fiyat indeksi, gelir indeksi, toplam ihracat ve kişi başı $\mathrm{CO}_{2}$ emisyonu ise çıktı değişkenleri olarak kullanılmıştır. VZA'nın CCR ve BCC modellerinin kullanıldığı çalışma sonucunda CCR modeline göre 16 ülkenin, BCC modeline göre ise 18 ülkenin etkin olduğu görülmüştür.

\section{Veri Zarflama Analizi}

VZA ilk olarak Farrell (1957)'in "The Measurement of Productive Efficiency" isimli çalışmasından yola çıkarak Charnes, Cooper ve Rhodes tarafından Europen Journal of Operations Research dergisinde 1978 yılında yayınlanmış olan "Measuring The Efficiency of Decision Making Units" isimli çalışmaları ile ortaya çıkmıştır. Bu makale ile VZA, üretilen mal ya da hizmet açısından benzer ekonomik karar verme biriminin (KVB) göreli etkinliklerinin ölçülmesi amacıyla geliştirilmiş bir yöntem olarak tanımlanmıştır (Cook ve Seiford, 2009: 1). 
VZA, doğrusal programlama teorisine dayanan ve birden fazla, farklı ölçeklerle ölçülmüş ya da farklı ölçü birimine sahip girdi ve çıktıların karşılaştırma yapmayı zorlaştırdığı durumlarda, KVB'nin göreceli etkinliğini ölçmeyi amaçlayan bir yöntemdir (Önsoy, 2013: 12). VZA'da kullanılan birçok model bulunmaktadır. Çalışmada kullanılacak olan model karar verici tarafından çalışmanın amacına ve kullanılacak olan varsayımlara göre belirlenir. Karar verici en az girdiyle aynı miktarda çıktıyı elde etmek istiyorsa girdi yönlü, aynı girdi miktarıyla daha fazla çıktıyı elde etmek istiyorsa çıktı yönlü modeli tercih etmelidir.

Bu çalışmada aynı girdi miktarıyla daha fazla çıktı elde edebilmek için çıktı yönlü CCR ve çıktı yönlü BCC modelleri kullanılmıştır. Çıktı yönlü CCR ve çıktı yönlü BCC modelleri ayrı ayrı incelenmiş ve sonuçlar yorumlanmıştır. Analiz sonucunda incelenen dönemde etkin ve etkin olmayan ülkeler belirlenerek etkin olmayan ülkelerin referans kümesinde bulunan ülkeler ve yoğunluk değerleri verilmektedir. VZA ile ülkelerin referans kümesindeki yoğunluk değerleri yardımıyla ülkelerin girdi ve çıktılarının hedef değerleri hesaplanmaktadır. Çalışmada kullanılan çıktı yönlü CCR ve BCC modelleri için etkinlik skorları Efficiency Measurement System (EMS) programı yardımıyla hesaplanmıştır.

VZA'nın önerilen ilk modeli CCR modeli ile teknik etkinlik ölçeğin sabit getirisi varsayımı altında ölçülmektedir. CCR modeli girdi yönlü ve çıktı yönlü olmak üzere iki şekilde tanımlanır. Girdi yönlü CCR modeli ölçeğe göre sabit getiri varsayımı ile toplam etkinliği ölçmektedir. Bu modelin amacı girdileri en aza indirerek verilen çıktı düzeylerini tahmin etmektir.

VZA'nın ana hedeflerinden biri KVB'lerin etkinlik durumlarının belirlenmesi iken diğeri etkin olmayan KVB'lerinin etkin hale gelebilmesi için kullanılacak ölçüt etkin KVB'lerdir. Bu KVB'lerin oluşturduğu küme referans kümesi olarak adlandırılır. (Çağlar, 2003: 28).

Etkin olmayan KVB'lerin etkin olması için girdi ve çıktılarında yapmaları gereken değişiklik miktarını gösteren potansiyel iyileştirme oranları hesaplanabilir. Potansiyel iyileştirme yüzdesi negatif orana sahipse etkin olmayan KVB'nin değişken değeri potansiyel iyileştirme oranında azaltılmalıdır. Eğer potansiyel iyileştirme yüzdesi pozitif orana sahipse etkin olmayan KVB'nin değişken değeri potansiyel iyileştirme oranında artırılmalıdır. Potansiyel iyileştirme oranı sıfırsa herhangi bir iyileştirme yapmaya gerek yoktur. Potansiyel iyileştirme oranlarının hesaplanması aşağıdaki eşitlikte verilmiştir (Özden, 2008: 173):

$$
\text { Potansiyel İyileștirme }=\frac{(\text { Hedef Değer }- \text { Gerçekleșen Değer })}{\text { Gerçekleşen Değer }} * 100
$$

Girdi yönlü CCR modelinde girdileri en aza indirerek verilen çıktı düzeylerini tahmin etmeyi amaçlayan modelken, çıktı yönlü CCR modeli ise girdi bileşiminde bir değişiklik yapmadan, çıktı bileşimini maksimize etmeyi amaçlayan modeldir (Adler vd., 2002: 251; Tepe, 2006: 88).

Banker, Charnes ve Cooper tarafından 1984 yılında ölçeğe göre değişen getiri varsayımı altında oluşturulan model ise BCC modeli olarak adlandırılmaktadır. BCC modelinde ölçeğe göre değişen getiri varsayımı altında her bir KVB için teknik etkinlik ölçülür. CCR modelinde KVB'nin etkin olması için hem teknik hem de ölçek etkin olması gerekirken BCC modelinde sadece teknik etkin olması yeterlidir (Bowlin, 1998: 9).

VZA modelleri yardımıyla CCR modeli ile bulunan etkinlik değerlerine teknik etkinlik, BCC modeli ile bulunan etkinlik değerlerine ise saf teknik etkinlik adı verilmektedir. Saf teknik etkinlik değerleri teknik etkinlik değerlerine eşit ya da daha büyük olabilmektedir. Bu iki etkinlik değeri arasındaki fark ölçek etkinliğinden kaynaklanmaktadır. Ölçek etkinliği, üretimde 
en uygun ölçeği bulabilme başarısıdır. Teknik etkinlik ve saf teknik etkinlik değerinin birbirine eşit olması durumunda değerlendirilen KVB'nin optimal ölçekte faaliyet gösterdiği söylenebilir. Aksi durumda ise KVB'nin ölçeğini değiştirmesi gerekmektedir. Ölçek etkinliği aşağıdaki gibi hesaplanır (Ulucan ve Karacabey, 2002: 107):

Ölçek Etkinlik $=\frac{\theta_{C C R}^{*}}{\theta_{B C C}^{*}}=\frac{\text { Teknik Etkinlik }}{\text { Saf Teknik Etkinlik }}$

\section{Veri Zarflama Analizi ile Ortadoğu ve Kuzey Afrika (MENA) Bölgesi'ndeki Ülkelerin Etkinliklerinin Analizi}

\subsection{Karar Verme Birimlerinin Seçilmesi}

VZA'nın ilk ve en önemli aşaması KVB'lerin seçilmesidir. Sonuçların doğru olması ve güvenilirliği açısından KVB'lerin fazla sayıda ve homojen olması önemlidir. Bu çalışmada MENA bölgesinde yer alan 22 ülkenin ekonomik etkinliklerinin analiz edilmesi amaçlanmıştır. Çalışma 22 MENA ülkesi ile sınırlı tutulmuştur. Dünya bankası verilerine göre MENA ülkeleri sırasıyla; BAE (Birleşik Arap Emirlikleri), Bahreyn, Cezayir, Cibuti, Fas, Filistin (Batı Şeria ve Gazze), Irak, İran, İsrail, Katar, Kuveyt, Libya, Lübnan, Malta, Mısır, Suriye, Suudi Arabistan, Tunus, Türkiye, Umman, Ürdün, Yemen'dir. Cibuti ve Filistin (Batı Şeria ve Gazze)'e ait bazı değişkenlerin verilerine ulaşılamadığı için bu iki ülke analize dâhil edilmemiştir. Geriye kalan 20 ülke birer KVB olarak alınarak ekonomik etkinlikler incelenmiştir.

\subsection{Girdi ve Çıktı Değişkenlerinin Belirlenmesi}

VZA'da kullanılacak olan girdi ve çıktı değişkenleri ülkelerin etkinliklerinin karşılaştırılmasında temel oluşturdukları için büyük özenle seçilmelidirler. Çalışmada kullanılan veriler ülkelerin ekonomik etkinlikleri ile ilgili literatürde yapılan çalışmalar dikkate alınarak seçilmiştir. Ayrıca tüm ülkeler için eksiksiz olarak elde edilebilecek değişkenler olmasına da özen gösterilmiştir. Belirlenen 4 tane girdi ve 3 tane çıktı değişkenlerine ait verilere The World Bank ve SESRIC (Statistical, Economic and Social Researchand Training Centre for Islamic Countries) veri tabanlarından ulaşılmıştır. Seçilen girdi ve çıktı değişkenleri Tablo 1'de verilmiştir. Çalışmada kullanılan değişkenlerin tanımlayıcı istatistikleri Tablo 2'de verilmiştir.

\section{Tablo 1: Çalışmada Kullanılan Girdi ve Çıktı Değişkenleri}

\begin{tabular}{llll}
\hline \multicolumn{2}{c}{ GiRDileR } & \multicolumn{1}{c}{ ÇıKTILAR } \\
\hline \hline & G1: Bağımlı Nüfus Oranı & $\bullet$ & Ç1: Kişi Başı GSYiH \\
$\bullet$ & G2: Enflasyon Oranı & $\bullet$ & Ç2: Mal Ihracatı \\
$\bullet$ & G3: İşsizlik Oranı & $\bullet$ & Ç3: İstihdam Oranı \\
$\bullet$ & G4: Mal İthalatı & & \\
\hline
\end{tabular}

Girdi ve çıktı değişkenlerinin çok fazla sayıda olması VZA'nın etkin ve etkin olmayan KVB'leri ayrıştırmada zorlanmasına neden olmaktadır. Bu bağlamda girdi ve çıktı değişkenlerinin sayıları ile KVB sayıları aralarındaki bağlantı konusunda farklı görüşler bulunmaktdır. Vassiloglou ve Giokas (1990) etkinliklerin doğru olarak ölçülebilmesi ve daha sağlıklı sonuçlar elde edilebilmesi için KVB sayısının girdi ve çıktı toplamının en az üç katı olması gerektiğini belirtmiştir. Ramanathan (2003) yaptığı bir çalışmada girdi ve çıktı toplamlarının en az 2 ya da 3 katı kadar KVB kullanılması gerektiğini savunmuştur. Norman ve Stoker (1991) ise kullanılacak girdi-çıktı sayısına bağı olarak ve deneyimlere dayanarak KVB sayısının en az 20 olması gerektiğini belirtmiştir (Ateş ve Esmer, 2013: 110). Boussofiane vd. (1991) girdi sayısı $m$, çıktı sayısı s ise KVB sayısının en az $m+s+1$ olması gerektiği görüşünü 
savunmaktadır (Özcan, 2007: 6). Bu çalışmada $m=4$ (Girdi Sayısı), s=3 (Çıktı Sayısı) ve $n=20$ (KVB Sayısı) olmak üzere;

- $\quad 2(m+s) \leq n$ için; $2(4+3) \leq 20$

- $20 \leq n$ için; $20 \leq 20$

- $\quad m+s+1 \leq n$ için; $4+3+1 \leq 20$

koşullarının sağlandığı söylenebilir.

Çalışmada kullanılan girdi ve çıktı değişkenlerine ilişkin tanımlar (http://www.worldbank.org/, 21.03.2016) ve değişkenlerin tanımlayıcı istatistikleri aşağıda verilmiştir.

Bağımlı nüfus oranı; çalışma çağındaki 15-64 yaş grubundaki her 100 kişi için 15 yaşından küçük veya 64 yaşından daha büyük yaş grubundaki kişilerin sayısıdır. 0-14 yaş ve 64 yaş üzerindeki kişilerin oluşturduğu nüfusun çalışma çağındaki kişilerin sayısına oranı olarak ifade edilir. Tablo 2'de değişkenlere ait tanımlayıcı istatistikler incelendiğinde bağımlı nüfus değişkeninde en yüksek değeri Irak $(79,23)$ alırken, en düşük değeri ise BAE $(17.47)$ 'nin aldığı gözlemlenmiştir. Tablo 2'ye göre Türkiye (50)'deki bağımlı nüfusun ise MENA ülkelerindeki bağımlı nüfus ortalamasının üstünde olduğu görülmektedir.

Enflasyon oranı; tüketici fiyat endeksi ile ölçülen yıllık olarak sabit ya da belirli aralıklarla mal ve hizmetin fiyatlarındaki yüzde değişim oranıdır. Tablo 2'de değişkenlere ait tanımlayıcı istatistikler incelendiğinde enflasyon oranı değişkeninde en yüksek değeri Suriye $(22,66)$ alırken, en düşük değeri ise Malta $(0,31)^{\prime}$ nın aldığı gözlemlenmiştir. Tablo 2'ye göre Türkiye $(8,85)^{\prime}$ deki enflasyon oranının ise MENA ülkelerindeki enflasyon oranı ortalamasının üzerinde olduğu görülmektedir.

Işşizlik oranı; çalışma yaşına gelmiş fakat iş bulamayan nüfusun toplam nüfusa oranı olarak ifade edilir. Bu oran ekonomik göstergelerin en önemlileri arasında yer almaktadır. Tablo 2'de değişkenlere ait tanımlayıcı istatistikler incelendiğinde işsizlik oranı değişkeninde en yüksek değeri Libya $(19,20)$ alırken, en düşük değeri ise Katar $(0,30)^{\prime} ı n$ aldığı gözlemlenmiştir. Tablo 2'ye göre Türkiye $(9,2)$ 'deki işsizlik oranının MENA ülkelerindeki işsizlik oranının ortalamasına yakın çıktığı görülmektedir.

Mal ithalatı; yurtdışında üretilmiş malların, ülkedeki alıcılar tarafından satın alınmasıdır. Çalışmada milyar ABD doları cinsinden veriler kullanılmıştır. Bu değişken uluslararası arenada diğer ülkeler tarafından bir ülkenin itibar nedeni sayılmaktadır. Bu yüzden mal ithalatı ülkenin ekonomik etkinliği için önemli bir göstergedir. Tablo 2'de değişkenlere ait tanımlayıcı istatistikler incelendiğinde en fazla ithalat yapan ülkenin BAE $(262,00)$, en az ithalat yapan ülkenin ise Malta $(6,47)$ olduğu gözlemlenmiştir. Tablo 2'ye göre Türkiye'deki mal ithalatının 242,18 ile MENA ülkelerindeki mal ithalatı ortalamasının üzerinde olduğu görülmektedir.

Kişi başı gayri safi yurtiçi hasıla (GSYIH); bir ülkede elde edilen toplam gelirin, kişi refahının bir göstergesi olan kişi başına düşen kısmını göstermektedir. Milli gelir bir ülkenin ekonomik gücünü gösteren önemli bir değişkendir. Kişi başı milli gelir ise o ülkede yaşayan kişilerin ortalama gelir düzeyi hakkında bilgi verici bir değişkendir. Çalışmada değişkene ait veriler ABD doları cinsinden alınmıştır. Bu değişkene ait eksik olan Malta'ya ait 2014 yılı verisi kendinden önceki beş yıllık verilerin ortalaması alınarak tamamlanmıştır. Tablo 2'de değişkenlere ait tanımlayıcı istatistikler incelendiğinde kişi başı GSYiH'sı en yüksek olan ülkenin Katar $(96732,40)$, en düşük olan ülkenin ise Yemen $(1418,08)$ olduğu gözlemlenmiştir. Burada kişi başı GSYiH'sı ortalamanın üzerinde olan ülkelerin birçoğu bölgedeki petrol ve doğal gaz 
rezervlerine sahip ülkelerdir. Tablo 2'ye göre Türkiye'deki kişi başı GSYiH ise 10515,01 olup MENA ülkelerindeki kişi başı GSYiH ortalamasının altında olduğu görülmektedir.

Mal ihracatı; bir malın döviz karşılığı yabancı ülkelere yapılan satışıdır. Çalışmada milyar ABD doları cinsinden veriler kullanılmıştır. Bu değişken aynı zamanda ülkelerin uluslararası arenadaki itibarının bir göstergesidir. Tablo 2'de değişkenlere ait tanımlayıcı istatistikler incelendiğinde en fazla ihracat yapan ülkenin $\operatorname{BAE}(359,00)$, en az ihracat yapan ülkenin ise Suriye $(2,00)$ olduğu gözlemlenmiştir. Tablo 2'ye göre Türkiye'deki mal ihracatının 157,64 ile MENA ülkelerindeki mal ihracatı ortalamasının üzerinde olduğu görülmektedir.

Istihdam oranı; 15 yaş ve üzerinde çalışma çağına gelmiş nüfusun genel nüfusa oranı olarak ele alınmaktadır. Tablo 2'de değişkenlere ait tanımlayıcı istatistikler incelendiğinde istihdam oranının en yüksek olduğu ülke Katar $(86,40)$, en düşük olduğu ülkenin ise Irak $(35,40)$ olduğu gözlemlenmiştir. Tablo 2'ye göre Türkiye $(44.80)^{\prime}$ deki istihdam oranının MENA ülkelerindeki istihdam oranının ortalamasının biraz altında olduğu görülmektedir.

Tablo 2: Çalışmada Kullanılan Değişkenlerin Tanımlayıcı İstatistikleri

\begin{tabular}{lrrrrrrr}
\hline & Bağımlı Nüfus & Enflasyon Oranı & $\begin{array}{r}\text { İssizlik } \\
\text { Oranı }\end{array}$ & $\begin{array}{r}\text { Mal } \\
\text { ithalatı }\end{array}$ & $\begin{array}{r}\text { Kişi Başı } \\
\text { GSYiH }\end{array}$ & $\begin{array}{r}\text { Mal } \\
\text { ihracatı }\end{array}$ & $\begin{array}{r}\text { istihdam } \\
\text { Oranı }\end{array}$ \\
\hline \hline En Büyük & 79,23 & 22,66 & 19,20 & 262,00 & 96732,40 & 359,00 & 86,40 \\
En Küçük & 17,47 & 0,31 & 0,30 & 6,47 & 1418,08 & 2,00 & 35,40 \\
Ortalama & 48,92 & 4,98 & 9,26 & 62,69 & 18731,77 & 80,26 & 50,63 \\
Ortanca & 50,08 & 2,81 & 9,35 & 34,94 & 8315,64 & 37,78 & 44,75 \\
Standart Sapma & 17,22 & 5,88 & 5,10 & 73,62 & 22950,12 & 104,91 & 14,37 \\
\hline
\end{tabular}

\subsection{Uygulama ve Analiz Sonuçlarının Yorumlanması}

Bu bölümde MENA bölgesinde yer alan 20 ülkenin 2014 yılına ait verileri kullanılarak göreli etkinlikleri çıktı yönlü CCR ve çıktı yönlü BCC modelleri ile analiz edilmiş ve sonuçlar yorumlanmıştır. Sonuçların yorumlanmasında etkinlik sonuçlarının göreli etkinlik skorları olduğuna dikkat edilmesi gerekmektedir. Analiz sonuçlarına göre bir ülkenin etkin olması demek o ülkenin diğer ülkelere ve analizde kullanılan girdi ve çıktılar açısından etkin olduğunu ifade etmektedir.

Yapılan analiz sonucunda çıktı yönlü CCR ve çıktı yönlü BCC modellerinden elde edilen etkinlik skorları, etkin KVB'ler için referans olma sayıları ve etkin olmayan KVB'ler için referansları gösterilmiştir (Bkz Tablo 3).

2014 yılına ait veriler kullanılarak EMS programı ile yapılan etkinlik analizi sonucu Tablo 3 incelendiğinde, çıktı yönlü CCR modeline göre teknik etkin ülke sayısı 7 bulunurken, teknik etkin olmayan ülke sayısının ise 13 olduğu görülmektedir. Teknik etkinlik skoru 1 olan ülkeler; BAE, Bahreyn, İsrail, Katar, Malta, Suudi Arabistan ve Umman'dır. Teknik etkin olan ülkelerden BAE 2 ülkeye, Bahreyn 5 ülkeye, İsrail 1 ülkeye, Katar 11 ülkeye, Malta 8 ülkeye, Suudi Arabistan 2 ülkeye ve Umman ise 3 ülkeye teknik etkin olabilmeleri için referans olmuştur. Türkiye'nin teknik etkinlik skoru 3,15'dir ve teknik etkin olmak için kendine BAE ve Katar'ı referans almaktadır. Teknik etkinlik skoru en düşük olan ülkeler; Cezayir $(2,54)$, Mısır $(4,60)$ ve Ürdün (2,79)'dür. Cezayir'in referans aldığı ülkeler; Katar, Malta, Suudi Arabistan ve Umman; Mısır'ın referans aldığı ülkeler; Bahreyn ve Katar ve Ürdün'ün referans aldığı ülkeler ise Bahreyn, Katar ve Malta'dır. 
20 ülkenin çıktı yönlü BCC modeline göre elde edilen etkinlik skorları, etkin KVB'ler için referans olma sayıları ve etkin olmayan KVB'ler için referansları Tablo 5 'te gösterilmektedir. Tablo 5 incelendiğinde saf teknik etkin ülke sayısı 7 bulunurken, saf teknik etkin olmayan ülke sayısının ise 13 olduğu görülmektedir. Saf teknik etkinlik skoru 1 olan ülkeler; BAE, Bahreyn, İsrail, Katar, Malta, Suudi Arabistan ve Umman'dır. Saf teknik etkin olan ülkelerden BAE 3 ülkeye, Bahreyn 5 ülkeye, İsrail 3 ülkeye, Katar 10 ülkeye, Malta 8 ülkeye, Suudi Arabistan 2 ülkeye ve Umman ise 2 ülkeye saf teknik etkin olabilmeleri için referans olmuştur. Türkiye'nin saf teknik etkinlik skoru 1,79'dur ve saf teknik etkin olmak için kendine BAE ve Katar'ı referans almaktadır. Saf teknik etkinlik skoru en düşük olan ülkeler; Cezayir $(2,11)$, Mısır $(2,01)$ ve Ürdün (1,99)'dür. Cezayir'in referans aldığı ülkeler; BAE, İsrail ve Katar; Mısır’ın referans aldığı ülke; Katar ve Ürdün'ün referans aldığı ülkeler ise Bahreyn, Katar ve Malta'dır.

Tablo 3: Çıktı Yönlü CCR ve BCC Çözümlerine Iliş̧in Etkinlik Skorları, Referansları ve Referans Olma Sayıları

\begin{tabular}{|c|c|c|c|c|c|c|}
\hline \multirow[b]{2}{*}{ KVB } & \multicolumn{3}{|c|}{ Çıktı Yönlü CCR } & \multicolumn{3}{|c|}{ Çıktı Yönlü BCC } \\
\hline & SKOR & REFERANS KÜMELER & $\begin{array}{l}\text { REFERANS } \\
\text { OLMA } \\
\text { SAYILARI }\end{array}$ & SKOR & $\begin{array}{l}\text { REFERANS } \\
\text { KÜMELER }\end{array}$ & $\begin{array}{c}\text { REFERANS } \\
\text { OLMA } \\
\text { SAYILARI }\end{array}$ \\
\hline BAE* & 1,000 & BAE (1) & 2 & 1,000 & BAE (1) & 3 \\
\hline Bahreyn* & 1,000 & Bahreyn (1) & 5 & 1,000 & Bahreyn (1) & 5 \\
\hline Cezayir & 2,543 & $\begin{array}{c}\text { Katar }(0,74), \\
\text { Malta }(0,57), \\
\text { S. Arabistan }(0,16) \text {, } \\
\text { Umman }(0,03)\end{array}$ & 0 & 2,116 & $\begin{array}{l}\text { BAE }(0,01) \text {, } \\
\text { İsrail }(0,06) \text {, } \\
\text { Katar }(0,93)\end{array}$ & 0 \\
\hline Fas & 1,140 & $\begin{array}{l}\text { İsrail }(0,29) \text {, } \\
\text { Malta }(0,56), \\
\text { Umman }(0,12)\end{array}$ & 0 & 1,138 & $\begin{array}{c}\text { BAE }(0,04) \text {, } \\
\text { İsrail }(0,14) \text {, } \\
\text { Malta }(0,79) \text {, } \\
\text { Umman }(0,04)\end{array}$ & 0 \\
\hline Irak & 1,735 & $\begin{array}{c}\text { Katar }(0,50), \\
\text { Malta }(0,11), \\
\text { S. Arabistan }(0,24)\end{array}$ & 0 & 1,706 & $\begin{array}{c}\text { Katar }(0,49), \\
\text { Malta }(0,27), \\
\text { S. Arabistan }(0,24)\end{array}$ & 0 \\
\hline İran & 2,148 & Katar $(1,42)$ & 0 & 1,813 & $\begin{array}{c}\text { Katar }(0,88), \\
\text { S. Arabistan }(0,12)\end{array}$ & 0 \\
\hline İsrail* & 1,000 & İsrail (1) & 1 & 1,000 & İsrail (1) & 3 \\
\hline Katar* & 1,000 & Katar (1) & 11 & 1,000 & Katar (1) & 10 \\
\hline Kuveyt & 1,121 & Katar $(0,91)$ & 0 & 1,100 & $\begin{array}{l}\text { Katar }(0,89) \text {, } \\
\text { Malta }(0,11)\end{array}$ & 0 \\
\hline Libya & 1,958 & $\begin{array}{c}\text { Bahreyn }(0,50), \\
\text { Katar }(0,22), \\
\text { Malta }(0,64)\end{array}$ & 0 & 1,674 & $\begin{array}{c}\text { Bahreyn }(0,75), \\
\text { Katar }(0,23), \\
\text { Malta }(0,02)\end{array}$ & 0 \\
\hline Lübnan & 1,342 & $\begin{array}{c}\text { BAE }(0,02), \\
\text { Katar }(0,07), \\
\text { Malta }(0,75), \\
\text { Umman }(0,26)\end{array}$ & 0 & 1,265 & $\begin{array}{l}\text { İsrail }(0,02) \text {, } \\
\text { Katar }(0,03) \text {, } \\
\text { Malta }(0,44) \text {, } \\
\text { Umman }(0,51)\end{array}$ & 0 \\
\hline Malta* & 1,000 & Malta (1) & 8 & 1,000 & Malta (1) & 8 \\
\hline
\end{tabular}




\begin{tabular}{|c|c|c|c|c|c|c|}
\hline Mısır & 4,597 & $\begin{array}{c}\text { Bahreyn }(1,09), \\
\text { Katar }(1,43)\end{array}$ & 0 & 2,019 & Katar $(1,00)$ & 0 \\
\hline Suriye & 1,299 & Malta $(1,04)$ & 0 & 1,269 & $\begin{array}{c}\text { Bahreyn }(0,03) \\
\text { Malta }(0,97)\end{array}$ & 0 \\
\hline Suudi Arabistan* & 1,000 & S. Arabistan (1) & 2 & 1,000 & S. Arabistan (1) & 2 \\
\hline Tunus & 2,527 & $\begin{array}{c}\text { Bahreyn }(1,33), \\
\text { Katar }(0,17)\end{array}$ & 0 & 1,851 & $\begin{array}{c}\text { Bahreyn }(0,52), \\
\text { Katar }(0,48)\end{array}$ & 0 \\
\hline Türkiye & 3,155 & $\begin{array}{l}\operatorname{BAE}(0,65), \\
\text { Katar }(1,97)\end{array}$ & 0 & 1,798 & $\begin{array}{l}\operatorname{BAE}(0,66) \text {, } \\
\text { Katar }(0,34)\end{array}$ & 0 \\
\hline Umman* & 1,000 & Umman (1) & 3 & 1,000 & Umman (1) & 2 \\
\hline Ürdün & 2,797 & $\begin{array}{c}\text { Bahreyn }(0,67), \\
\text { Katar }(0,23), \\
\text { Malta }(0,81)\end{array}$ & 0 & 1,999 & $\begin{array}{c}\text { Bahreyn }(0,56), \\
\text { Katar }(0,41), \\
\text { Malta }(0,04)\end{array}$ & 0 \\
\hline Yemen & 2,006 & $\begin{array}{c}\text { Bahreyn }(0,03), \\
\text { Katar }(0,08), \\
\text { Malta }(1,48)\end{array}$ & 0 & 1,606 & $\begin{array}{c}\text { Bahreyn }(0,88), \\
\text { Malta }(0,12)\end{array}$ & 0 \\
\hline
\end{tabular}

Tablo 4'te çıktı yönlü CCR modeli sonuçlarına göre skor ve girdi-çıktı değişkenlerinin gerçekleşen değerleri, hedef değerleri ve potansiyel iyileştirme oranları gösterilmiştir. Etkin olan KVB'lerin hedef değerlerinde bir değişiklik yapılmasına gerek olmadığı için hedef değerleri ile gerçek değerleri aynıdır. Bu yüzden etkin KVB'lerin potansiyel iyileştirme oranları O'dır. Etkin olmayan KVB'ler için ise girdi değişkenlerinde azalma, çıktı değişkenlerinde ise artış yapılıp yapılmaması gerektiği hakkında bilgi vermektedir.

Tablo 4: Çıktı Yönlü CCR Modeline Ait Değişkenlerin Gerçekleşen Değerleri, Hedef Değerleri ve Potansiyel lyileştirme Oranları

\begin{tabular}{|c|c|c|c|c|c|c|c|c|c|}
\hline KVB & & G1 & G2 & G3 & G4 & Ç1 & Ç2 & Ç3 & Skor \\
\hline & Gerçek & 17,47 & 2,34 & 3,60 & 262,00 & 43962,71 & 359,00 & 77,60 & \\
\hline \multirow[t]{3}{*}{ BAE } & Hedef Değer & 17,47 & 2,34 & 3,60 & 262,00 & 43962,71 & 359,00 & 77,60 & 1,00 \\
\hline & İyileştirme & 0,00 & 0,00 & 0,00 & 0,00 & 0,00 & 0,00 & 0,00 & \\
\hline & Gerçek & 30,86 & 2,77 & 3,90 & 13,91 & 24855,22 & 20,47 & 67,20 & \\
\hline \multirow[t]{3}{*}{ Bahreyn } & Hedef Değer & 30,86 & 2,77 & 3,90 & 13,91 & 24855,22 & 20,47 & 67,20 & 1,00 \\
\hline & İyileştirme & 0,00 & 0,00 & 0,00 & 0,00 & 0,00 & 0,00 & 0,00 & \\
\hline & Gerçek & 51,54 & 2,92 & 9,50 & 58,33 & 5484,07 & 62,96 & 40,00 & \\
\hline \multirow[t]{3}{*}{ Cezayir } & Hedef Değer & 51,54 & 2,92 & 4,70 & 58,33 & 87840,08 & 160,08 & 101,71 & 2,54 \\
\hline & İyileştirme & 0,00 & 0,00 & $-50,53$ & 0,00 & 1501,73 & 154,27 & 154,27 & \\
\hline & Gerçek & 50,16 & 0,44 & 10,20 & 45,83 & 3190,31 & 23,66 & 45,50 & \\
\hline \multirow[t]{3}{*}{ Fas } & Hedef Değer & 50,16 & 0,44 & 5,94 & 28,93 & 24886,35 & 26,98 & 51,88 & 1,14 \\
\hline & İyileştirme & 0,00 & 0,00 & $-41,76$ & $-36,87$ & 680,06 & 14,02 & 14,02 & \\
\hline & Gerçek & 79,23 & 2,24 & 16,40 & 59,00 & 6420,37 & 88,97 & 35,40 & \\
\hline \multirow[t]{2}{*}{ Irak } & Hedef Değer & 26,58 & 2,24 & 2,16 & 59,00 & 56779,48 & 154,32 & 61,40 & 1,73 \\
\hline & İyileştirme & $-66,45$ & 0,00 & $-86,83$ & 0,00 & 784,36 & 73,45 & 73,45 & \\
\hline
\end{tabular}


Eskişehir Osmangazi Üniversitesi IïBF Dergisi

\begin{tabular}{|c|c|c|c|c|c|c|c|c|c|}
\hline & Gerçek & 39,84 & 17,24 & 12,80 & 52,00 & 5442,87 & 88,80 & 39,60 & \\
\hline \multirow[t]{3}{*}{ İran } & Hedef Değer & 27,91 & 4,38 & 0,43 & 52,00 & 137433,76 & 190,73 & 122,76 & 2,15 \\
\hline & İyileştirme & $-29,95$ & $-74,61$ & $-96,64$ & 0,00 & 2425,02 & 114,79 & 209,99 & \\
\hline & Gerçek & 63,41 & 0,48 & 6,10 & 75,34 & 37207,99 & 68,12 & 59,10 & \\
\hline \multirow[t]{3}{*}{ İsrail } & Hedef Değer & 63,41 & 0,48 & 6,10 & 75,34 & 37207,99 & 68,12 & 59,10 & 1,00 \\
\hline & İyileştirme & 0,00 & 0,00 & 0,00 & 0,00 & 0,00 & 0,00 & 0,00 & \\
\hline & Gerçek & 19,64 & 3,08 & 0,30 & 36,60 & 96732,40 & 134,25 & 86,40 & \\
\hline \multirow[t]{3}{*}{ Katar } & Hedef Değer & 19,64 & 3,08 & 0,30 & 36,60 & 96732,40 & 134,25 & 86,40 & 1,00 \\
\hline & İyileştirme & 0,00 & 0,00 & 0,00 & 0,00 & 0,00 & 0,00 & 0,00 & \\
\hline & Gerçek & 32,32 & 2,91 & 3,00 & 33,27 & 43593,70 & 108,86 & 66,50 & \\
\hline \multirow[t]{3}{*}{ Kuveyt } & Hedef Değer & 17,85 & 2,80 & 0,27 & 33,27 & 87931,29 & 122,04 & 78,54 & 1,12 \\
\hline & İyileştirme & $-44,77$ & $-3,78$ & $-91,00$ & 0,00 & 101,71 & 12,10 & 18,10 & \\
\hline & Gerçek & 51,82 & 2,80 & 19,20 & 19,00 & 6573,39 & 21,00 & 42,60 & \\
\hline \multirow[t]{3}{*}{ Libya } & Hedef Değer & 51,82 & 2,24 & 5,79 & 19,00 & 46911,74 & 41,12 & 83,42 & 1,96 \\
\hline & İyileştirme & 0,00 & $-20,00$ & $-69,84$ & 0,00 & 613,66 & 95,81 & 95,81 & \\
\hline & Gerçek & 47,47 & 0,75 & 6,40 & 21,14 & 10057,89 & 4,55 & 44,70 & \\
\hline \multirow[t]{3}{*}{ Lübnan } & Hedef Değer & 47,47 & 0,75 & 6,40 & 21,14 & 28183,41 & 31,50 & 59,99 & 1,34 \\
\hline & İyileştirme & 0,00 & 0,00 & 0,00 & 0,00 & 180,21 & 592,69 & 34,20 & \\
\hline & Gerçek & 50,20 & 0,31 & 5,90 & 6,47 & 21126,06 & 2,80 & 48,80 & \\
\hline \multirow[t]{3}{*}{ Malta } & Hedef Değer & 50,20 & 0,31 & 5,90 & 6,47 & 21126,06 & 2,80 & 48,80 & 1,00 \\
\hline & İyileştirme & 0,00 & 0,00 & 0,00 & 0,00 & 0,00 & 0,00 & 0,00 & \\
\hline & Gerçek & 61,69 & 10,15 & 13,20 & 67,49 & 3198,70 & 27,09 & 42,80 & \\
\hline \multirow[t]{3}{*}{ Misır } & Hedef Değer & 61,69 & 7,43 & 4,68 & 67,49 & 165419,76 & 214,31 & 196,75 & 4,60 \\
\hline & İyileştirme & 0,00 & $-26,81$ & $-64,55$ & 0,00 & 5071,48 & 691,05 & 359,69 & \\
\hline & Gerçek & 68,76 & 22,66 & 10,80 & 6,70 & 1542,76 & 2,00 & 38,90 & \\
\hline \multirow[t]{3}{*}{ Suriye } & Hedef Değer & 52,00 & 0,32 & 6,11 & 6,70 & 21881,84 & 2,91 & 50,55 & 1,30 \\
\hline & İyileştirme & $-24,37$ & $-98,59$ & $-43,43$ & 0,00 & 1318,36 & 45,44 & 29,94 & \\
\hline & Gerçek & 46,24 & 2,67 & 5,60 & 163,00 & 24160,96 & 353,51 & 52,10 & \\
\hline \multirow[t]{3}{*}{ Suudi Arabistan } & Hedef Değer & 46,24 & 2,67 & 5,60 & 163,00 & 24160,96 & 353,51 & 52,10 & 1,00 \\
\hline & İyileştirme & 0,00 & 0,00 & 0,00 & 0,00 & 0,00 & 0,00 & 0,00 & \\
\hline & Gerçek & 44,48 & 4,94 & 13,30 & 24,83 & 4420,70 & 16,76 & 41,30 & \\
\hline \multirow[t]{3}{*}{ Tunus } & Hedef Değer & 44,48 & 4,22 & 5,25 & 24,83 & 49759,78 & 50,38 & 104,37 & 2,53 \\
\hline & İyileştirme & 0,00 & $-14,58$ & $-60,53$ & 0,00 & 1025,61 & 200,70 & 152,72 & \\
\hline & Gerçek & 50,00 & 8,85 & 9,20 & 242,18 & 10515,01 & 157,64 & 44,80 & \\
\hline \multirow[t]{2}{*}{ Türkiye } & Hedef Değer & 50,00 & 7,58 & 2,93 & 242,18 & 218934,68 & 497,36 & 220,44 & 3,15 \\
\hline & İyileştirme & 0,00 & $-14,34$ & $-68,15$ & 0,00 & 1982,12 & 215,50 & 392,06 & \\
\hline
\end{tabular}




\begin{tabular}{cccccccccc} 
& Gerçek & 30,96 & 1,01 & 7,20 & 30,72 & 19309,61 & 48,47 & 61,50 & \\
\multirow{4}{*}{ Umman } & Hedef Değer & 30,96 & 1,01 & 7,20 & 30,72 & 19309,61 & 48,47 & 61,50 & 1,00 \\
& iyileştirme & 0,00 & 0,00 & 0,00 & 0,00 & 0,00 & 0,00 & 0,00 & \\
& Gerçek & 65,63 & 2,81 & 11,10 & 22,87 & 5422,57 & 8,22 & 37,20 & \\
\multirow{4}{*}{ Ürdün } & Hedef Değer & 65,63 & 2,81 & 7,44 & 22,87 & 55688,22 & 46,51 & 104,06 & 2,80 \\
& iyileştirme & 0,00 & 0,00 & $-32,97$ & 0,00 & 926,97 & 466,16 & 179,73 & \\
& Gerçek & 76,64 & 8,16 & 17,40 & 13,03 & 1418,08 & 8,00 & 40,50 & \\
\multirow{4}{*}{ Yemen } & Hedef Değer & 76,64 & 0,80 & 8,85 & 13,03 & 40051,50 & 16,05 & 81,23 & 2,00 \\
& iyileştirme & 0,00 & $-90,20$ & $-49,14$ & 0,00 & 2724,35 & 100,57 & 100,57 & \\
& & & & & & & & &
\end{tabular}

Çıktı yönlü CCR modeline göre teknik etkin olan BAE, Bahreyn, İsrail, Katar, Malta, Suudi Arabistan ve Umman ülkeleri için gerçek ve hedef değerler aynıdır. Bu yüzden potansiyel iyileştirme oranları da 0'dır.

Türkiye 3,15 etkinlik skoruyla teknik etkin olmayan bir KVB'dir. Bu ülkenin gerçek değerleri ile hedef değerleri karşılaştırıldığında birinci girdi (bağımlı nüfus oranı) ve dördüncü girdi (mal ithalatı) değişkenlerinde herhangi bir değişim olmadığı görülmektedir. Bu yüzden gerçek değer ile hedef değerleri aynı ve potansiyel iyileştirme oranları ise 0 'dır. İkinci girdi (enflasyon oranı) ve üçüncü girdi (işsizlik oranı) değişkenlerinde ise gerçek ve hedef değerler birbirinden farklıdır. Girdi değişkenlerinden 8,85 olan enflasyon oranı \%14,34 oranında azaltılarak 7,58 ve 9,20 olan işsizlik oranı ise $\% 68,15$ oranında azaltılarak 2,93 olduğunda Türkiye etkin bir KVB olabilir. Çıktı değişkenleri incelendiğinde ise gerçek ve hedef değerler farklı olduğu görülmektedir. Çıktı değişkenlerinden 10515,01 olan kişi başı GSYiH \%1982,12 oranında artırılarak 218934,68 olduğunda, 157,64 olan mal ihracatı \%215,50 oranında artırılarak 497,36 olduğunda ve 44,80 olan istihdam oranı ise $\% 392,06$ oranında artırılarak 220,44 olduğunda etkin olmayan Türkiye etkin KVB olabilecektir.

Mısır 4,60 etkinlik skoruyla teknik etkinlik skoru en düşük olan KVB'dir. Bu ülkenin gerçek değerleri ile hedef değerleri karşılaştırıldığında birinci girdi (bağımlı nüfus oranı) ve dördüncü girdi (mal ithalatı) değişkenlerinde herhangi bir değişim olmadığı görülmektedir. Bu yüzden gerçek değer ile hedef değerleri aynı ve potansiyel iyileştirme oranları ise 0 'dır. İkinci girdi (enflasyon oranı) ve üçüncü girdi (işsizlik oranı) değişkenlerinde ise gerçek ve hedef değerler birbirinden farklıdır. Girdi değişkenlerinden 10,15 olan enflasyon oranı \%26,81 oranında azaltılarak 7,43 ve 13,20 olan işsizlik oranı ise $\% 64,55$ oranında azaltılarak 4,68 olduğunda Mısır etkin bir KVB olabilir. Çıktı değişkenleri incelendiğinde ise gerçek ve hedef değerler farklı olduğu görülmektedir. Çıktı değişkenlerinden 3198,70 olan kişi başı GSYiH \%5071,48 oranında artırılarak 165419,76 olduğunda, 27,09 olan mal ihracatı \%691,05 oranında artırılarak 214,31 olduğunda ve 42,80 olan istihdam oranı ise \%359,69 oranında artırılarak 196,75 olduğunda etkin olmayan Mısır etkin KVB olabilecektir.

Çıktı yönlü CCR modeli incelendiğinde teknik etkin olmayan diğer KVB'ler için de gerçek değerlerinde yapılacak olan potansiyel iyileştirme oranları ile ulaşılacak hedef değerleri Tablo 4 'ten incelenip benzer yorumlar yapılabilmektedir.

Tablo 5'de, çıktı yönlü BCC modeli sonuçlarına göre skor ve girdi-çıktı değişkenlerinin gerçekleşen değerleri, hedef değerleri ve potansiyel iyileştirme oranları gösterilmiştir. 
Eskişehir Osmangazi Üniversitesi iiBF Dergisi

Tablo 5: Çıktı Yönlü BCC Modeline Ait Değişkenlerin Gerçekleşen Değerleri, Hedef Değerleri ve Potansiyel lyileștirme Oranları

\begin{tabular}{|c|c|c|c|c|c|c|c|c|c|}
\hline KVB & & G1 & G2 & G3 & G4 & Ç1 & Ç2 & Ç3 & Skor \\
\hline & Gerçek & 17,47 & 2,34 & 3,60 & 262,00 & $4 \quad 43962,71$ & 359,00 & 777,60 & \\
\hline \multirow[t]{3}{*}{ BAE } & Hedef Değer & 17,47 & 2,34 & 3,60 & 262,00 & 43962,71 & 359,00 & 77,60 & 1,00 \\
\hline & İyileştirme & 0,00 & 0,00 & 0,00 & 0,00 & 0,00 & 0,00 & 0,00 & \\
\hline & Gerçek & 30,86 & 2,77 & 3,90 & 13,91 & 24855,22 & 20,47 & 67,20 & \\
\hline \multirow[t]{3}{*}{ Bahreyn } & Hedef Değer & 30,86 & 2,77 & 3,90 & 13,91 & 24855,22 & 20,47 & 67,20 & 1,00 \\
\hline & İyileştirme & 0,00 & 0,00 & 0,00 & 0,00 & 0,00 & 0,00 & 0,00 & \\
\hline & Gerçek & 51,54 & 2,92 & 9,50 & 58,33 & 5484,07 & 62,96 & 40,00 & \\
\hline \multirow[t]{3}{*}{ Cezayir } & Hedef Değer & 22,24 & 2,92 & 0,69 & 41,88 & 92469,70 & 133,23 & 84,65 & 2,12 \\
\hline & İyileştirme & $-56,85$ & 0,00 & $-92,74$ & $-28,20$ & 1586,15 & 111,62 & 111,62 & \\
\hline & Gerçek & 50,16 & 0,44 & 10,20 & 45,83 & 3190,31 & 23,66 & 45,50 & \\
\hline \multirow[t]{3}{*}{ Fas } & Hedef Değer & 50,16 & 0,44 & 5,89 & 26,58 & 24183,21 & 26,93 & 51,78 & 1,14 \\
\hline & İyileştirme & 0,00 & 0,00 & $-42,25$ & $-42,00$ & 658,02 & 13,80 & 13,80 & \\
\hline & Gerçek & 79,23 & 2,24 & 16,40 & 59,00 & 6420,37 & 88,97 & 35,40 & \\
\hline \multirow[t]{3}{*}{ Irak } & Hedef Değer & 34,30 & 2,24 & 3,09 & 59,00 & 58825,33 & 151,76 & 67,99 & 1,70 \\
\hline & İyileştirme & $-56,71$ & 0,00 & $-81,16$ & 0,00 & 816,23 & 70,58 & 92,05 & \\
\hline & Gerçek & 39,84 & 17,24 & 12,80 & 52,00 & 5442,87 & 88,80 & 39,60 & \\
\hline \multirow[t]{3}{*}{ İran } & Hedef Değer & 22,88 & 3,04 & 0,95 & 52,00 & 87890,88 & 160,97 & 82,22 & 1,81 \\
\hline & İyileştirme & $-42,57$ & $-82,39$ & $-92,58$ & 0,00 & 1514,79 & 81,27 & 107,63 & \\
\hline & Gerçek & 63,41 & 0,48 & 6,10 & 75,34 & 37207,99 & 68,12 & 59,10 & \\
\hline \multirow[t]{3}{*}{ İsrail } & Hedef Değer & 63,41 & 0,48 & 6,10 & 75,34 & 37207,99 & 68,12 & 59,10 & 1,00 \\
\hline & İyileştirme & 0,00 & 0,00 & 0,00 & 0,00 & 0,00 & 0,00 & 0,00 & \\
\hline & Gerçek & 19,64 & 3,08 & 0,30 & 36,60 & 96732,40 & 134,25 & 86,40 & \\
\hline \multirow[t]{3}{*}{ Katar } & Hedef Değer & 19,64 & 3,08 & 0,30 & 36,60 & 96732,40 & 134,25 & 86,40 & 1,00 \\
\hline & İyileştirme & 0,00 & 0,00 & 0,00 & 0,00 & 0,00 & 0,00 & 0,00 & \\
\hline & Gerçek & 32,32 & 2,91 & 3,00 & 33,27 & 43593,70 & 108,86 & 66,50 & \\
\hline \multirow[t]{3}{*}{ Kuveyt } & Hedef Değer & 23,02 & 2,78 & 0,92 & 33,27 & 88378,43 & 119,73 & 82,25 & 1,10 \\
\hline & İyileştirme & $-28,77$ & $-4,47$ & $-69,33$ & 0,00 & 102,73 & 9,98 & 23,68 & \\
\hline & Gerçek & 51,82 & 2,80 & 19,20 & 19,00 & 6573,39 & 21,00 & 42,60 & \\
\hline \multirow[t]{3}{*}{ Libya } & Hedef Değer & 28,60 & 2,80 & 3,11 & 19,00 & 41296,67 & 46,30 & 71,31 & 1,67 \\
\hline & İyileştirme & $-44,81$ & 0,00 & $-83,80$ & 0,00 & 528,24 & 120,50 & 67,40 & \\
\hline & Gerçek & 47,47 & 0,75 & 6,40 & 21,14 & 10057,89 & 4,55 & 44,70 & \\
\hline \multirow[t]{3}{*}{ Lübnan } & Hedef Değer & 39,90 & 0,75 & 6,40 & 21,14 & 22745,97 & 31,12 & 56,53 & 1,26 \\
\hline & İyileştirme & $-15,95$ & 0,00 & 0,00 & 0,00 & 126,15 & 584,29 & 26,46 & \\
\hline & Gerçek & 50,20 & 0,31 & 5,90 & 6,47 & 21126,06 & 2,80 & 48,80 & \\
\hline \multirow[t]{3}{*}{ Malta } & Hedef Değer & 50,20 & 0,31 & 5,90 & 6,47 & 21126,06 & 2,80 & 48,80 & 1,00 \\
\hline & İyileştirme & 0,00 & 0,00 & 0,00 & 0,00 & 0,00 & 0,00 & 0,00 & \\
\hline & Gerçek & 61,69 & 10,15 & 13,20 & 67,49 & 3198,70 & 27,09 & 42,80 & \\
\hline \multirow[t]{3}{*}{ Misır } & Hedef Değer & 19,64 & 3,09 & 0,30 & 36,60 & 96732,43 & 134,25 & 86,40 & 2,02 \\
\hline & İyileştirme & $-68,16$ & $-69,59$ & $-97,73$ & $-45,77$ & 2924,12 & 395,54 & 101,87 & \\
\hline & Gerçek & 68,76 & 22,66 & 10,80 & 6,70 & 1542,76 & 2,00 & 38,90 & \\
\hline \multirow[t]{3}{*}{ Suriye } & Hedef Değer & 49,60 & 0,39 & 5,84 & 6,70 & 21242,01 & 3,36 & 49,37 & 1,27 \\
\hline & İyileştirme & $-27,87$ & $-98,29$ & $-45,93$ & 0,00 & 1276,88 & 67,92 & 26,92 & \\
\hline & Gerçek & 46,24 & 2,67 & 5,60 & 163,00 & 24160,96 & 353,51 & 52,10 & \\
\hline \multirow[t]{3}{*}{ Suudi Arabistan } & Hedef Değer & 46,24 & 2,67 & 5,60 & 163,00 & 24160,96 & 353,51 & 52,10 & 1,00 \\
\hline & İyileştirme & 0,00 & 0,00 & 0,00 & 0,00 & 0,00 & 0,00 & 0,00 & \\
\hline & Gerçek & 44,48 & 4,94 & 13,30 & 24,83 & 4420,70 & 16,76 & 41,30 & \\
\hline \multirow[t]{3}{*}{ Tunus } & Hedef Değer & 25,46 & 2,92 & 2,17 & 24,83 & 59440,00 & 75,22 & 76,44 & 1,85 \\
\hline & İyileştirme & $-42,76$ & $-40,91$ & $-83,68$ & 0,00 & 1244,58 & 348,93 & 85,08 & \\
\hline & Gerçek & 50,00 & 8,85 & 9,20 & 242,18 & 10515,01 & 157,64 & 44,80 & \\
\hline \multirow[t]{2}{*}{ Türkiye } & Hedef Değer & 18,20 & 2,59 & 2,49 & 186,24 & 61698,07 & 283,47 & 80,56 & 1,80 \\
\hline & İyileştirme & $-63,60$ & $-70,70$ & $-72,93$ & $-23,10$ & 486,76 & 79,82 & 79,82 & \\
\hline
\end{tabular}




\begin{tabular}{|c|c|c|c|c|c|c|c|c|c|}
\hline & Gerçek & 30,96 & 1,01 & 7,20 & 30,72 & 19309,61 & 48,47 & 61,50 & \\
\hline \multirow[t]{3}{*}{ Umman } & Hedef Değer & 30,96 & 1,01 & 7,20 & 30,72 & 19309,61 & 48,47 & 61,50 & 1,00 \\
\hline & İyileştirme & 0,00 & 0,00 & 0,00 & 0,00 & 0,00 & 0,00 & 0,00 & \\
\hline & Gerçek & 65,63 & 2,81 & 11,10 & 22,87 & 5422,57 & 8,22 & 37,20 & \\
\hline \multirow[t]{3}{*}{ Ürdün } & Hedef Değer & 26,98 & 2,81 & 2,51 & 22,87 & 53924,96 & 66,07 & 74,35 & 1,99 \\
\hline & İyileştirme & $-58,89$ & 0,00 & $-77,39$ & 0,00 & 894,45 & 704,25 & 99,87 & \\
\hline & Gerçek & 76,64 & 8,16 & 17,40 & 13,03 & 1418,08 & 8,00 & 40,50 & \\
\hline \multirow[t]{2}{*}{ Yemen } & Hedef Değer & 33,14 & 2,48 & 4,14 & 13,03 & 24414,17 & 18,38 & 65,02 & 1,60 \\
\hline & İyileştirme & $-56,76$ & $-69,61$ & $-76,21$ & 0,00 & 1621,64 & 129,80 & 60,55 & \\
\hline
\end{tabular}

Çıktı yönlü BCC modeline göre saf teknik etkin olan BAE, Bahreyn, İsrail, Katar, Malta, Suudi Arabistan ve Umman ülkeleri için gerçek ve hedef değerler aynıdır. Bu yüzden potansiyel iyileştirme oranları da 0 'dır.

Türkiye 1,80 etkinlik skoruyla saf teknik etkin olmayan bir KVB'dir. Bütün girdi değişkenleri incelendiğinde gerçek ve hedef değerler farklı olduğu görülmektedir. Türkiye'nin etkin bir KVB olması için bağımlı nüfus oranı $\% 63,60$, enflasyon oranı $\% 70,70$, işsizlik oranı $\% 72,93$ ve mal ithalatı ise $\% 23,10$ oranında azaltılmalıdır. Bu durumda hedef değerleri bağımlı nüfus oranı için 18,20 , enflasyon oranı için 2,59, işsizlik oranı için 2,49 ve mal ithalatı için ise 186,24 olur. Çıktı değişkenleri incelendiğinde ise gerçek ve hedef değerlerin farklı olduğu görülmektedir. Çıktı değişkenlerinden 10515,01 olan kişi başı GSYiH \%486,76 oranında artırılarak 61698,07 olduğunda, 157,64 olan mal ihracatı $\% 79,82$ oranında artırılarak 283,47 olduğunda ve 44,80 olan istihdam oranı ise $\% 79,82$ oranında artırılarak 80,56 olduğunda etkin olmayan Türkiye etkin KVB olabilecektir.

Cezayir 2,12 etkinlik skoruyla saf teknik etkinlik skoru en düşük olan KVB'dir. İkinci girdi (enflasyon oranı) değişkeninde herhangi bir değişim olmadığı görülmektedir. Bu yüzden gerçek değer ile hedef değeri aynı ve potansiyel iyileştirme oranı ise 0'dır. Birinci girdi (bağımlı nüfus oranı), üçüncü girdi (işsizlik oranı) ve dördüncü girdi (mal ithalatı) değişkenlerinde ise gerçek ve hedef değerler birbirinden farklıdır. Girdi değişkenlerinden 51,54 olan bağımlı nüfus oranı \%56,85 oranında azaltılarak 22,24, 9,50 olan işsizlik oranı \%92,74 oranında azaltılarak 0,69 ve 58,33 olan mal ithalatı $\% 28,20$ oranında azaltılarak 41,88 olduğunda Cezayir etkin bir KVB olabilir. Çıktı değişkenleri incelendiğinde ise gerçek ve hedef değerler farklı olduğu görülmektedir. Çıktı değişkenlerinden 5484,07 olan kişi başı GSYiH \%1586,15 oranında artırılarak 92469,70 olduğunda, 62,96 olan mal ihracatı \%111,62 oranında artırılarak 133,23 olduğunda ve 40,00 olan istihdam oranı ise $\% 111,62$ oranında artırılarak 84,65 olduğunda etkin olmayan Cezayir etkin KVB olabilecektir.

Çıktı yönlü BCC modeli incelendiğinde saf teknik etkin olmayan diğer KVB'ler için de gerçek değerlerinde yapılacak olan potansiyel iyileştirme oranları ile ulaşılacak hedef değerleri Tablo 5 'den incelenip benzer yorumlar yapılabilmektedir.

Çalışmada yer alan ülkelerin sıralamalarını görmek için ayrıca çıktı yönlü CCR ve çıktı yönlü BCC modellerine ilişkin süper etkinlik skorları da bulunmuştur. Modeller ayrı ayrı çözülmüş ve her birinden elde edilen etkinlik skorları (ES) ve süper etkinlik skorları (SES) Tablo 6'da gösterilmiştir. Çıktı yönlü BCC modelindeki süper etkinlik skorlarında "Big" ifadesi çok uç skorların olduğunu göstermektedir. 
Eskişehir Osmangazi Üniversitesi ïBß Dergisi

Tablo 6: KVB'lerin Süper Etkinlik Skorları ile Sıralanması

\begin{tabular}{|c|c|c|c|c|}
\hline \multirow[b]{2}{*}{ KVB } & \multicolumn{2}{|c|}{ ÇIKTI YÖNLÜ CCR } & \multicolumn{2}{|c|}{ ÇIKTI YÖNLÜ BCC } \\
\hline & CCR-ES & CCR-SES & BCC-ES & BCC-SES \\
\hline BAE & 1,00 & 0,37 & 1,00 & Big \\
\hline Bahreyn & 1,00 & 0,74 & 1,00 & Big \\
\hline Cezayir & 2,54 & 2,54 & 2,12 & 2,12 \\
\hline Fas & 1,14 & 1,14 & 1,14 & 1,14 \\
\hline Irak & 1,74 & 1,73 & 1,71 & 1,71 \\
\hline İran & 2,15 & 2,15 & 1,81 & 1,81 \\
\hline İsrail & 1,00 & 0,56 & 1,00 & 0,46 \\
\hline Katar & 1,00 & 0,05 & 1,00 & Big \\
\hline Kuveyt & 1,12 & 1,12 & 1,10 & 1,10 \\
\hline Libya & 1,96 & 1,96 & 1,57 & 1,67 \\
\hline Lübnan & 1,34 & 1,34 & 1,27 & 1,26 \\
\hline Malta & 1,00 & 0,29 & 1,00 & Big \\
\hline Misir & 4,60 & 4,60 & 2,02 & 2,02 \\
\hline Suriye & 1,30 & 1,30 & 1,27 & 1,27 \\
\hline Suudi Arabistan & 1,00 & 0,74 & 1,00 & 0,74 \\
\hline Tunus & 2,53 & 2,53 & 1,85 & 1,85 \\
\hline Türkiye & 3,16 & 3,16 & 1,80 & 1,80 \\
\hline Umman & 1,00 & 0,80 & 1,00 & Big \\
\hline Ürdün & 2,80 & 2,80 & 2,00 & 2,00 \\
\hline Yemen & 2,01 & 2,01 & 1,61 & 1,61 \\
\hline
\end{tabular}

Tablo 6 incelendiğinde; ikinci sütunda çıktı yönlü CCR modelinin çözülmesi sonucunda elde edilen etkinlik skorlar (CCR-ES) yer almaktadır. Buna göre 7 ülkenin etkin olduğu görülmektedir. Bu ülkeler; BAE, Bahreyn, İsrail, Katar, Malta, Suudi Arabistan ve Umman'dır. Geriye kalan 13 ülke ise etkin değildir. Etkinlik skoru en yüksek olan ülkeler yukarıda verilen 7 ülkedir ve etkinlik skorları 1,00'dir. Ancak bu ülkelerin de kendi aralarında nasıl sıralandığını bilmek önemlidir. Bu sıralamayı Tablo 6 'da yer alan çıktı yönlü CCR süper etkinlik modelinin çözülmesi sonucunda elde edilen süper etkinlik skorları (CCR-SES) ile görmek mümkündür. Çıktı yönlü CCR modelinde süper etkinlik skorları incelendiğinde en yüksekten en düşüğe doğru Katar, Malta, BAE, İsrail, Suudi Arabistan, Bahreyn, Umman, Kuveyt, Fas, Suriye, Lübnan, Irak, Libya, Yemen, İran ve Tunus şeklinde sıralandığı görülmektedir. Tablo 6'da bulunan 4. sütuna bakıldığında ise çıktı yönlü BCC modelinin çözülmesi sonucunda elde edilen etkinlik skorları (BCC-ES) yer almaktadır. Buna göre 7 ülke etkindir ve bu ülkeler; BAE, Bahreyn, İsrail, Katar, Malta, Suudi Arabistan ve Umman'dır. Tablo 6'nın son sütununda ise çıktı yönlü BCC süper etkinlik skorları (BCC-SES) verilmiştir. Ülkelerin süper etkinlik skorları bakımından en yüksekten en düşüğe doğru sıralaması ise BAE- Bahreyn- Katar- MaltaUmman, İsrail, Suudi Arabistan, Kuveyt, Fas, Lübnan, Suriye, Yemen, Libya, Irak, Türkiye, İran, Tunus, Ürdün, Mısır ve Cezayir'dir. 
Son olarak tüm değişkenler girdi ve çıktı değişkenleri olarak ayrılmadan hiyerarşik kümeleme analizi testine tabi tutulmuştur. Hiyerarşik kümeleme analizi yöntemine göre üç kümeli çözümde Katar'ın ilk kümede yer aldığı, BAE, Bahreyn, İsrail, Kuveyt, Malta, Suudi Arabistan ve Umman'ın ikinci kümede yer aldığı diğer ülkelerinde üçüncü kümede yer aldığı tespit edilmiştir. VZA ile etkin ve etkin olmayan ülkeler olarak tespit edilmiş olan ülkelerin homojen olarak birbirinden ayrıldığı ve süper etkinlik skorlarının kümeleme analizi sonuçlarıyla büyük oranda örtüştüğü sonucuna varılmıştır.

\section{Sonuç}

Teknolojide yaşanan hızlı gelişmeler, pazarların küreselleşmesi, iletişimin artması, dünya çapında hızlı bilgi alışverişinin ve ulaşımın kolaylaşması, serbest ticaret engellerinin kaldırıması ülkelerin ulusal ekonomilerini önemli ölçüde etkilemekte ve rekabeti büyük ölçüde arttırmaktadır. Kaynakların her türlü ihtiyaca cevap veremediği günümüz koşullarında, mevcut kaynakların optimal şekilde değerlendirilmesi ve mümkün olan en az girdiyi kullanarak en fazla çıktının elde edilmesi bir zorunluluktur. Kıyasıya rekabet koşullarının meydana getirdiği bu zorunluluk, karar verme birimlerini, öncelikle kendilerini tanımaya, daha sonra rakiplerini tanımaya ve son olarak da her ikisini birbiriyle kıyaslayarak en etkin üretim koşullarına ulaşmak için gerekli tedbirleri almaya yöneltmiştir. Bu noktada etkinlik analizleri önem kazanmaktadır.

Etkinlik analizleri üç başlık altında toplanabilir. Bunlar; oran analizi, parametrik yöntemler ve parametrik olmayan yöntemlerdir. Tek girdi ile tek çıktı üretilen koşullarda girdinin, çıktıya oranı alınarak yapılan oran analizi sade ve basit olması nedeniyle sıklıkla tercih edilmektedir. Benzer şekilde birden fazla girdi kullanılarak tek bir çıktı elde edilen durumlar için de parametrik yöntemler kullanılabilmektedir. Bununla birlikte karar verme birimler elde edilen sonuçlara göre hem kendi hem de rakiplerinin durumlarını değerlendirebilmektedirler. Parametrik olmayan yöntemler ise birden fazla girdi ve birden fazla çıktı olduğu durumlarda tercih edilen etkinlik analiz yöntemidir. Bu çalışmada birden fazla girdi ve çıktının bulunduğu durumlarda en iyi gözlemlere göre etkinlik ölçümü yapabilen, parametrik olmayan bir yöntem olan VZA kullanılmıştır.

Çalışmada MENA bölgesinde yer alan 20 ülkenin 2014 yılı ekonomik etkinlikleri belirlenmiştir. Ekonomik etkinliklerinin belirlenmesi için ekonomik faktörler girdi ve çıktı değişkenleri olarak tanımlanmıştır. Bu noktada literatür araştırmaları ve dünya genelinde ülke değerlendirmelerinde kullanılan değişkenler dikkate alınarak dört girdi ve üç çıktıdan oluşturulan bir model ortaya konmuştur. Girdi olarak bağımlı nüfus oranı, enflasyon oranı, işsizlik oranı, mal ithalatı, çıktı olarak ise kişi başı GSYiH, mal ihracatı ve istihdam oranı kullanılmıştır.

Analizler "Efficiency Measurement System" programı ile hem CCR modeli hem de BCC modeli kullanılarak yapılmıştır. Ölçeğe göre değişken getiri durumunun sağladığı esneklik sayesinde BCC yöntemiyle yapılan analiz sonuçlarında etkin ülke sayılarında artış olduğu gözlemlenmiştir. Etkinlik değerleri, ülkenin değerlendirmeye alınan MENA ülkeleri arasındaki görece etkinliğini göstermektedir. Bir ülkenin etkin olması da, sadece belirlenen girdi ve çıktılar açısından diğer ülkelere göre etkin olduğunu ifade etmektedir.

Ramanathan (2006), Orta Doğu ve Kuzey Afrika (MENA) Bölgesinde yer alan 18 ülkenin ekonomik ve sosyal performanslarını VZA ile karşılaştırmıştır. Ramanathan yaptığı bu çalışmada toplam işgücünün nüfusa oranı, doğuşta beklenen yaşam süresi, ilköğretimdeki 
öğretmenlerin sayısı ve kişi başı GSYiH değişkenleri girdi, yaş bağımlılık oranı, okuma yazma bilmeyenlerin oranı ve bebek ölüm oranı değişkenleri ise çıktı olarak kullanmıştır. Yapılan analiz sonucunda Bahreyn, Ürdün, Kuveyt ve BAE en verimli, Yemen ise en verimsiz ülke olmuştur. Bu çalışmada ise elde edilen verilere ve kullanılan değişkenlere göre 7 ülke teknik ve saf teknik etkin bulunmuştur. Elde edilen sonuçlara göre, BAE, Bahreyn, İsrail, Katar, Malta, Suudi Arabistan ve Umman'ın teknik ve saf teknik etkin olduğu görülmüştür. Bunun yanında Cezayir, Fas, Irak, İran, Kuveyt, Libya, Lübnan, Mısır, Suriye, Tunus, Türkiye, Ürdün ve Yemen'in de teknik ve saf teknik etkin olmadığı görülmüştür. Ayrıca yapılan analiz sonuçlarına göre etkinlik skorları ve girdi-çıktı değişkenlerinin hedef değerleri ve potansiyel iyileştirme oranları gösterilmiştir. Etkin olan KVB'lerin hedef değerlerinde bir değişiklik yapılmasına gerek olmadığı için hedef değerleri ile gerçek değerleri aynıdır. Bu yüzden etkin KVB'lerin potansiyel iyileştirme oranları 0'dır. Etkin olmayan KVB'ler için ise girdi değişkenlerinde azalma, çıktı değişkenlerinde ise artış yapılıp yapılmaması gerektiği hakkında bilgi verilmektedir.

Bölgenin ekonomik gücünün kaynağı büyük ölçüde sahip olduğu zengin petrol rezervleridir. Arap ve Fars topraklarında çıkan petrol, MENA ülkelerinin özdeşleştiği temel hammadde sayılmaktadır. Petrolün çıktığı her ülke tarih boyunca yabancı ülkelerin emperyal savaş planlarının bir parçası olmuş ve her petrol ülkesi kendi içinde de sınıfsal çelişkilere ve isyanlara sahne olmuştur. Bu da MENA bölgesinin küresel ekonomi içindeki gelişimini olumsuz etkilemektedir. MENA bölgesinde ekonomik entegrasyon çalışmalarının bölge ülkeleri arasında ekonomik iş birlikteliklerinin artmasına ve ülkelerin ekonomik büyümelerine katkı sağlamasında olumlu bir etken olacağı düşünülmektedir. Çalışmada petrol rezervlerine sahip olan ülkelerin birçoğunun hem teknik hem de saf teknik etkin oldukları görülmektedir.

$\mathrm{Bu}$ çalışmada, uygulanan analiz neticesinde etkin çıkmayan ülkelerin ekonomik değişkenlerini verimli bir şekilde kullanmadıklarını söylemek doğru değildir. Elde edilen sonuçlar, yapılan araştırmada kullanılan girdi ve çıktı değişkenlerine de bağlıdır. Yani girdilere veya çıktılara yeni değişkenler eklendiğinde veya çıkarıldığında farklı sonuçlara ulaşılabileceği gibi, değişik VZA modelleri kullanıldığında da yine farklı sonuçlar elde edilebileceği göz önünde bulundurulmalıdır. Çalışmada ülkelerin ekonomik model ile etkinliği incelenmiştir. Çalışmada kullanılan verilerden bazıları Cibuti ve Filistin için elde edilememiştir. Bu sebeple iki ülke modele dâhil edilmemiştir. Bundan sonra yapılacak çalışmalarda eksik ülkelere ait verilere ulaşarak bu ülkelerde modele dâhil edilebilir, farklı bir yıla ait verilere ulaşılarak ülkelerin yakın zamandaki ekonomik etkinlikleri daha geniş bir perspektiften incelenebilir. 


\section{Kaynaklar}

Adler, Nicole; Friedman, Lea ve Sinuany-Stern, Zilla (2002), "Review of Ranking Methods in The Data Envelopment Analysis Context", European Journal of Operational Research, (140): 249-265.

Aslankaraoğlu, Nesrin (2006), "Veri Zarflama Analizi ve Temel Bileşenler Analizi ile Avrupa Birliği Ülkelerinin Sıralanması", Yüksek Lisans Tezi, Gazi Üniversitesi Fen Bilimleri Enstitüsü, Ankara.

Ateş, Alparslan; Esmer, Soner (2013), "Türk Konteyner Terminalleri Üzerinde 2009 Yılı Küresel Finans Krizinin Etkileri”, Sayıştay Dergisi, (91): 105-125.

Boussofiane, A.; Dyson, R. ve Rhodes, E. (1991), “Applied Data Envelopment Analysis", European Journal of Operational Research, 2(6): 1-15.

Bowlin, William F. (1998), "Measuring Performance: An Introduction to Data Envelopment Analysis (DEA)", The Journal of Cost Analysis, 15(2): 3-27.

Charnes, Abraham; Cooper, William W. ve Rhodes, Edward (1978), "Measuring the efficiency of decision making units", European Journal of Operational Research,(2): 429-444.

Cook, Wade D.; Seiford, Larry M. (2009), "Data Envelopment Analysis (DEA) - Thirty Years On”, European Journal of Operational Research, (192): 1-17.

Çağlar, Atalay (2003), "Veri Zarflama Analizi ile Belediyelerin Etkinlik Ölçümü”, Doktora Tezi, Hacettepe Üniversitesi Fen Bilimleri Enstitüsü, Ankara.

Deliktaş, Ertuğrul (2008), "The Comparison of Technical Efficiency and Productivity Growth in Transition Countries and the Soviet Union Countries", International Conference on Emerging Issues in a Globalizing World, 91-107.

Demir, Ayhan; Bakırcı, Fehim (2014), “OECD Üyesi Ülkelerin Ekonomik Etkinliklerinin Veri Zarflama Analiziyle Ölçümü”, Atatürk Üniversitesi Iktisadi ve Idari Bilimler Dergisi, 28(2): 109-132.

Demirci, Ayhan (2012), “OECD Üyesi Ülkelerin Ekonomik ve Sosyal Etkinliklerinin Veri Zarflama Analizi Yöntemiyle Belirlenmesi”, Doktora Tezi, Atatürk Üniversitesi Sosyal Bilimler Enstitüsü, Erzurum.

Demireli, Erhan; Yüksek Özdemir, Aslı (2013), "Seçilmiş Avrupa Ülkelerinde Makroekonomik Performans Ölçümü: Şans Kısıtlı Veri Zarflama Analizi ile Bir Uygulama”, Dumlupınar Üniversitesi Sosyal Bilimler Dergisi, (37): 303-320.

Devlin, Julia C. (2010). Challeges of Economic Development in the Middle East and North Africa Region, London: World Scientific.

Drucker, Peter F. (1994), “Kapitalist Ötesi Toplum”, (Çev. B. Çorakçı), İstanbul: İnkılap Kitapevi.

Farrell, Michael James (1957), "The Measurement of Productive Efficiency", Journal of The Royal Statistical Society, 120(3): 253-290.

Genç, Hamdi; Sayım, Ferhat (Ed.). (2011), “Ortadoğu ve Kuzey Afrika Ülkelerinin Ekonomik Yapısı” Bursa: MKM Yayınları.

Güran, Mehmet Cahit; Cingi, Selçuk (2002), “Devletin Ekonomik Müdahalelerinin Etkinliği”, Akdeniz i.i.B.F. Dergisi, (3): 56-89.

HSCB Bank. (2011), "Turkishtime Global Export MENA”, HSCB Banka A.Ş.

http://www.sesric.org/baseind-step1.php, (Erişim: 15.12.2015).

http://databank.worldbank.org/data/reports.aspx?Code=NY.GDP.MKTP.CD\&id=af3ce82b\&report_name=Popular_ind icators\&populartype=series\&ispopular=y\#, (Erişim: 15.12.2015).

http://www.worldbank.org/, (Erişim: 21.03.2016).

Kalaycı, İrfan (2011), “Afrika'nın Melez Yüzü, 'MENA': Makro İktisadi Göstergelere ve Küresel Endekslere Göre 'Manası'”, Avrasya Etüdleri, (40): 175-199.

Karabulut, Kerem; Ersungur, Şaban Mustafa ve Polat, Özgür (2008), “Avrupa Birliği Ülkeleri ve Türkiye'nin Ekonomik Performanslarının Karşılaştırılması: Veri Zarflama Analizi”, iktisadi ve Idari Bilimler Dergisi, 22(1): 1-11.

Kavuncubaşı, Şahin; Ersoy, Korkut (1995), “Hastanelerde Teknik Verimlilik Ölçümü”, Amme Idaresi Dergisi, (28): 77-92.

Koçak, Habip; Çilingirtürk, Ahmet Mete (2011), “AB Ülkeleri ve Aday Ülkelerin Kaynak Kullanımında Etkinliklerinin Karşılaştırmalı Analizi”, İstanbul Üniversitesi İşletme Fakültesi Dergisi, 40(2): 166-175.

Martić, Milan; Savić, Gordana (2001), "An Application of DEA for Comparative Analysis and Ranking of Regions in Serbia With Regards to Social-Economic Development”, Europen Journal of Operational Research, 132:343-356. 


\section{Eskişehir Osmangazi Üniversitesi IïB Dergisi}

Mohamad, Nordin (2007), "A Linear Programming Formulation of Macroeconomic Performance: The Case of Asia Pacific", Matematika, 23(1): 29-40.

Mohamad, Nordin H. ; Said, Fatimah B. (2011), "Comparing Macroeconomic Performance og OIC Member Countries", International Journal of Economics and Managemen Sciences, 1(3): 90-104.

Öner, Burçin (2013), "Türkiye'de İllerin Ekonomik Performanslarının Veri Zarflama Analizi ve Temel Bileşenler Analizi Yöntemleri ile Değerlendirilmesi”, Yüksek Lisans Tezi, Ondokuz Mayıs Üniversitesi Fen Bilimleri Enstitüsü, Samsun.

Önsoy, Ebru (2013), "Veri Zarflama Analizi Kullanılarak Kargo Şirketlerinin Performanslarının Değerlendirilmesi”, Yüksek Lisans Tezi, Gazi Üniversitesi Fen Bilimleri Enstitüsü, Ankara.

Özcan, Gözde (2007), "Veri Zarflama Analizi ve Bankacılık Sektöründe Bir Uygulama”, Yüksek Lisans Tezi, Dumlupınar Üniversitesi Fen Bilimleri Enstitüsü, Kütahya.

Özden, Ünal H. (2008), "Veri Zarflama Analizi (VZA) ile Türkiye’deki Vakıf Üniversitelerinin Etkinliğinin Ölçülmesi”, İstanbul Üniversitesi Işletme Fakültesi Dergisi, 37(2): 167-185.

Ramanathan, Ramu (2003), An Introduction to Data Envelopment Analysis A Tool for Performance Measurement, India: SAGE Publications.

Ramanathan, Ramakrishnan (2006), "Evaluating The Comparative Performance Of Countries Of The Middle East and North Africa: A DEA Application”, Socio-Economic Planning Sciences, (40): 156-167.

Sözen, İlyas (2011), "MENA Bölgesi Doğal Kaynakları”, Genç, Hamdi ve Sayım, Ferhat (Ed.). “Ortadoğu ve Kuzey Afrika Ülkelerinin Ekonomik Yapısı", Bursa: MKM Yayınları: 120-150.

Tepe, Mübeyyen (2006), “Kıyaslama Çalışmasında Veri Zarflama Analizi Kullanımı”, Yüksek Lisans Tezi, İstanbul Teknik Üniversitesi Fen Bilimleri Enstitüsü, İstanbul.

Ulucan, Aydın; Karacabey, Ali Argun (2002), “iMKB Hisse Senedi Piyasasının Teknik Etkinliğinin AB Aday ve Üye Ülkelerle Karşılaştırmalı Analizi”, Ankara Avrupa Çalışmaları Dergisi, 2 (3): 101-111.

Vassiloglou, M.; Giokas, Demetrios (1990), “A Study of The Relative Efficiency of Bank Branches: An Application of Data Envelopment Analysis", The Journal of the Operational Research Society, 41(7): 591- 597. 